\title{
Revisiting the Myth of Irishness and Heroism-An Analysis of W.B. Yeats' The Green Helmet
}

\author{
Joanna Zadarko \\ Adam Mickiewicz University in Poznań, Poznań, Poland

\begin{abstract}
Using Sabina J. Müller's theory of myth, this paper will analyze the deconstruction and revision of myths in The Green Helmet. Irish mythology, as described by Müller, has in its inheritance a myth of Ireland being personified in an image of a woman, a goddess of the land. This Ireland-as-woman image, as well as Irish heroism and their fighting spirit will be investigated in Yeats' drama to show its simplification and to mock its nature. The analysis will also give an insight into the diversified and complex image of the Irish nation.
\end{abstract} \\ Keywords: myths, Irish drama, postcolonial drama, Yeats
}

\section{Introduction}

From the eighteenth century onwards, Irish mythology entered the Anglo-Irish tradition, yet it is still preserved in Irish literary output. In The Green Helmet, W.B. Yeats, one of the leading figures of the Celtic Literary Revival and Irish Renaissance, that aimed at restoring Irish culture and language, made an attempt to demythologize two of them, heroism and Irishness, which seem to be crucial in Irish mythology. The play shows how Yeats, incorporating the Cuchulainn character, satirizes the stereotypical perception of the Irish being a deluded and drunken nation. Irish mythology has in its inheritance a myth of Ireland being personified in the image of a woman, a goddess of the land. This Ireland-as-woman image, as well as Irish heroism will be investigated in Yeats' drama to show its simplification and to mock its nature. Using Sabina J. Müller's theory of myth, this paper will analyze the deconstruction and revision of myths in The Green Helmet.

\section{Theoretical Framework}

As Müller described it, a theory of myth has to explain the function of myths and how literary works achieve specific effects by applying them. The creation of a myth can be traced back to the 12th century and one of the mythograhpers that focuses on the creation of the myth is Mircea Eliade, for whom all myths are religious, being based on the fundamental principle of the sacred and the profane. The first one can have, for Eliade, a threefold effect on the latter one: "hierophany creates a sacred space, (...) establishes cosmos, order within profane, chaotic space. (...) creates absolute reality" (Müller, 2007, p. 10). Further on, Müller states that a religious person takes part in mythical time, in illo tempore, and that sacred time is nonhistorical-people endeavor to "regain the sacred time by periodically reintegrating it into profane time by means of rites" (Müller, 2007, p. 11).

Joanna Zadarko, MA, Faculty of English, Adam Mickiewicz University in Poznań. 
By definition, any theory of myth should be applicable to all kinds of them, but practice shows something contrary. For example, Freudian and Jungian theories of myth are more suitable for hero myths. They are both associated with the nature of dreams, yet while Freud relates myths to sexual wishes, Jung claims that myths abet psychological growth. Myths, being the preconscious psyche, make the monsters, gods, and heroes more archetypes, making their adventures symbolic representations of the ego's consciousness. At the same time, as Muller puts it, the Jungian and psychological approach is applicable to both primitive individuals as well as modern society.

Primitive people feel safe and protected, because they live in a world watched over by gods. (...) If modern people want to experience safety and harmony, they must discover the self and establish a connection with the unconscious. Thus myths have for primitive and modern human beings alike the function of giving meaning to life (...). (Müller, 2007, p. 24)

Celtic mythology touched upon the motif of female figures as well as land-as-woman theme long before it entered the Anglo-Irish tradition. Following Rosalind Clarks's steps of its development, the image of a woman in Celtic mythology started from the goddess of fertility, further changing into the pseudo-historical woman and after the year 1000 standing for an allegorical land. The final stage for Clark is the 19th-century Ireland-as-woman motif. This image was also linked with the Irish sovereignty myth, where female figures appeared in three different dimensions: "as beautiful maidens, powerful sexual women or as an old hag" (Müller, 2007, p. 35). Later on, the aisling poems and their translation, patriotic song, and folklore, the 18th century witnessed the emergence of Cathleen Ni Houlihan.

Cathleen was present in Irish culture and literature since that time but it was Yeats who revived her figure, representing Ireland and standing for its personification as a sovereignty, earth pagan goddess and a woman who the Irish went to fight and die for. Yet, while she brought fertility, she also demanded sacrifice. She was still a goddess but there was no sovereignty—-she did not have her own land, she was just striving to reclaim her four green lands.

However, the most famous hero in Irish mythology is Cuchulainn, about whom legends and myths form a part of the Ulster Cycle. He was also called the Irish Achilles (Ellis, 1987, p. 72). Having a mortal mother and a divine father, Cuchulainn is mostly famous for his single-handed defense of Ulster in the war of the Táin. Cuchulainn was married to Emer, whose hand also required a lot of effort and struggle from him. He is also a tragic hero- he dies on a battlefield while taking revenge for the death of the king of Munster. Defeated, exhausted and dying, he ties himself up to a pillar so that he can stand with his feet on the ground and face the eyes of his enemies. He was a champion of all Ireland.

William Butler Yeats was almost as much a legend as the hero he was writing about. The founder of the National Theatre Society, the Abbey Theatre, a leading figure of the Irish Literary Revival, and a 1923 Nobel Prize winner, he was the poet and dramatist of the Irish nation. Despite the huge success of his poems, Yeats considered himself predominantly a dramatist. With his two dozen plays and the establishment the Abbey Theatre, he made Dublin the theatrical and dramatic centre of cultural Europe at the beginning of the 20th century, and also brought the Irish culture and traditions into the English-speaking world (Sternlicht, 1998, p. 46).

Yeats incorporated mythical characters a number of times, those mainly being Cathleen ni Houlihan and Cuchulain. She is the main character of one of his plays - Catleen ni Houlihan from 1902. His favourite Ulster 
Cycle hero was a character of five of his plays: On Baile's Strand (1904), The Green Helmet (1910), At the Hawks Well (1916), The Only Jealousy of Emer (1919), and The Death of Cuchulain (1939). All five plays touch on the life, adventures, and death of Cuchulainn, often employing mystical and symbolic motifs, as well as the Noh dramatic tradition (At the Hawk's Well and The Only Jealousy of Emer). Nevertheless, it is The Green Helmet, where Yeats decides to de-mythologize the Irishness and uncover the human vanities, giving a realistic and amusing picture of the Irish heroes and their wives.

\section{Analysis}

The Green Helmet, subtitled "An heroic farce" begins with the arrival of Cuhulainn and the appearance of the green helmet which is thrown by the Red Man, who is going to appear again towards the end of the play. There are three men - Cuchulainn, and two other Irish warriors - Conall and Laegaire. All three of them want to have the green helmet, which is a symbol of superiority. Once the Red Man puts it on the ground in front of them, they are fighting over it with each other:

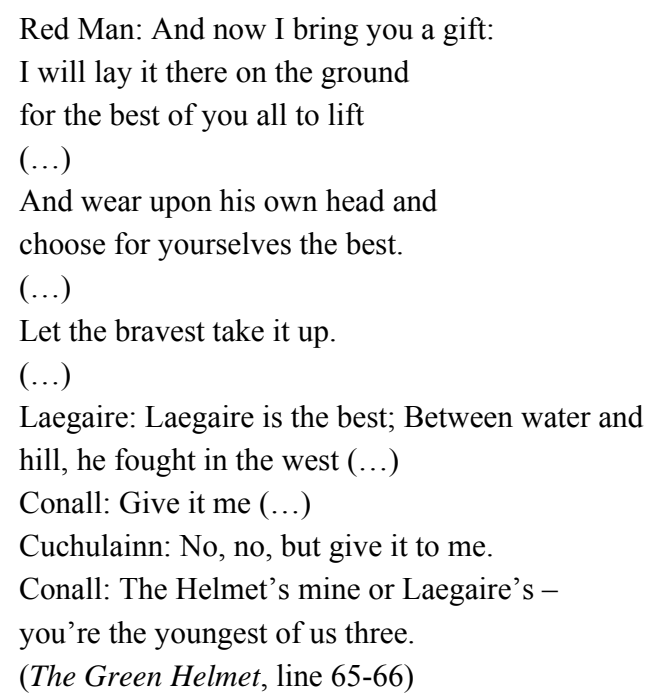

The three men are boasting about their courage, fearless deeds, and heroic attitude which give all of them the right to have and wear the noble green helmet. They swell with pride, looking at the helmet in their hands. The whole scene, however, is far from heroic, rather it is down-to-earth and shows self-pride and inability to reach a compromise, which Yeats might have mirrored in the Irish nation. Overtly brave fighters and men of their nation, yet giving a false impression. Secular and human vanity almost lost them. Fortunately, in the same scene, Cuchulainn comes to save the honour of all three and fills the helmet with ale and asks the other warriors to drink with him so that all of them would be equal and no one would feel superior or inferior. They all drink from the helmet and Cuchulainn throws it into the sea.

The above scene also demonstrates the Jungian theory described by Müller. It illustrates how the presence of mythology and gods, in this case the mythical figure of the Red Man, and the importance of the green helmet, helps people find meaning in their lives. The possession of the green helmet, or any other attribute of superiority, might have a purpose in a warrior's life. Fighting over it, as in the scene above, demonstrates, however, that it was not also accompanied by heroic behavior or a noble deed. 
Not only is heroism presented and de-mythologized in the play. Further on, we can observed how Yeats revised the Ireland-as-woman image. As Müller puts it, "the personification of Ireland as it appears in nationalist discourse and traditional literature simplifies" (Müller, 2007, p. 78). The woman is both a passive and at the same symbolic figure, with no complex feelings or ambitions, or she may be presented as it tempers with the history of the Irish people. Also bearing in mind the previously mentioned sovereignty of a woman that stands for Ireland in Celtic mythology, Yeats gives us quiet a contrary picture of Irish women.

A second amusing episode in the Green Helmet comes with a scene where the women of the three warriors - Cuchulainn, Conall, and Laegaire's wives — want to enter the building, and all three of them would like to enter first, since they feel they deserve supremacy due to their husbands' noble feats or other achievements. The exchange of their arguments is comical:

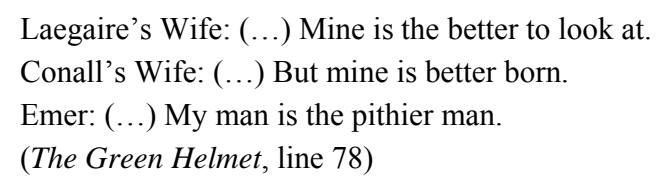

The three women cannot agree upon the order of their entrance. Every wife wants to enter first, feeling superior to the others. One might say that the image of Irish woman as a strong, regal, and powerful figure who stands up for the nation, at the same time denoting the allegorical green fields and Ireland itself is here shattered and diminished. Female vanity comes in its place showing how shallow, arrogant, and self-centered Irish women can be. The Ireland-as-woman image is also not simplified, nor is the image of woman, since the three ladies in Yeats' play show mere pretension and conceit. The author made them appear devoid of any mythological or divine qualities. The Irishness, woman as a symbol of the land, the personification of Ireland, is somehow prone to human error and temptations While Jung stated that myths abet psychological growth, here one can observe the clashing representation of women. Prone to vanity and with no ability to reach a compromise for the better good, these Irish women are imperfect and fail to control their ego or consciousness. Being superior is the chief aim of the three ladies. The scene, however, is once again saved by Cuchulainn who breaks the door and lets the three ladies enter simultaneously, indicating at the same time their equality.

Towards the end of the play, the Red Man emerges again and demands his debt be paid, and for one head cut off. Cuchulainn saves the situation once more and steps out, willing to be the victim. He volunteers to sacrifice himself in the name of and for the sake of his people. Nevertheless, his speech just before he wants to give himself to the Red Man, uncovers some of the blemishes of his character:

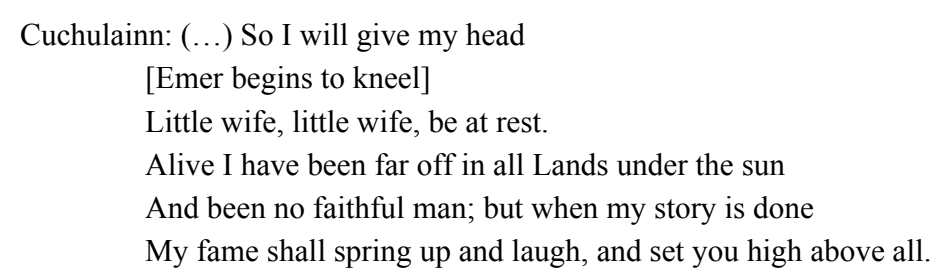

(The Green Helmet, line 88)

Cuchulainn displays heroism in his willingness to sacrifice himself for the nation and allow his head to be cut off. His courage and warrior spirit cannot be denied, yet he also reveals one of his characteristics that is less 
noble in its nature. He faces his wife's begging him not to sacrifice himself, and to answer her pleading admits that he was not a faithful husband while away from home, which apparently happened fairly frequently. Although having betrayed Emer a number of times, at same time breaking his marriage vows, he does not feel sorry for what he did and he even explains to his wife that thanks to his other deeds she will be raised up in the world. The mythical figure of Cuchulainn, even though he makes the huge sacrifice of his own life, is devalued and diminished. He is a human and earthly figure driven by his sexual desires. His weaknesses are also mentioned in the very last passages of the play, in the final speech of the Red Man: "the hand that loves to scatter, the life that like a gambler's throw (...)" (The Green Helmet, line 91). Bodily, mortal and sexual motifs drove Cuchulainn, the greatest warrior in Ireland, to succumb to his own weaknesses.

\section{Conclusion}

As has been presented, Yeats managed to deconstruct the myth of both heroism, in the character of Cuchulainn and the other Irish warriors, as well as the myth of Ireland-as-woman. The three warriors showed no understanding and merely pride, wanting to posses the green helmet. Lack of humility and modesty revealed their faulty nature. The image of woman standing for the notion of Ireland and Irishness was also ridiculed by Yeats. The three ladies present in Yeats' play were vain and self-centered to the extent that they also could not reach a solution, nor they could reach a compromise. Bereft of regal mythical virtues or female grace, they were stubborn and uncompromising to the very end. Superiority over others was more important to them. Finally, Cuchulainn himself proved to be of faulty, human nature, as well-admitting to have cheated on his wife and showing resentment towards his wife's attitude. The Green Helmet shows how the divine and regal nature of myth is deconstructed by the human vanities that Yeats uncovers throughout the play. A deluded nation, unable to reach a compromise, that is the image presented by Yeats. A hero prone to human errors and a woman clothed in vanity and stubbornness. Nevertheless, Yeats also presented Cuchulainn as a hero who is ultimately able to find solutions to problems without leaving anyone feeling inferior, and as a hero who is willing to sacrifice himself for the life of his people. Some virtues of a true warrior and a man of his nation are still there among the Irish for Yeats. The myth of Irishness and heroism was thus ridiculed and deconstructed, yet it was also revised. Perhaps, for contemporary Ireland, which is a postcolonial nation struggling in a search for identity in an English-speaking world, it is now time to revise their myths again, as a source of inspiration and cultural identity.

\section{References}

Ellis, P. B. (1987). A dictionary of Irish mythology. Oxford: Oxford University Press.

Foster, R. F. (1989). The Oxford history of Ireland. Oxford: Oxford University Press.

Müller, S. J. (2007). Through the mythograhers's eye: Myth and legend in the work of Seamus Heaney and Eavan Boland. Göttingen: Hubert \& Co.

Murray, C. (1997). Twentieth-century Irish drama: Mirror up the nation. Syracuse: Syracuse University Press.

Sternlicht, S. (1998). A reader's guide to modern Irish drama. Syracuse: Syracuse University Press.

Yeats, W. B. (1912). The Green Helmet. London: MacMillan \& Co. 